\title{
PROBLEMS OF IMPLEMENTING A BALANCED SCORECARD AS A MANAGEMENT TOOL IN UNIVERSITIES
}

\author{
Maria Arzamastseva, ${ }^{1}$ Marina Khayrullina ${ }^{2}$
}

\begin{abstract}
With the globalization of the economy, close attention should be given to the strategic management of higher education institutions as representatives of one type of company. The main problem of university management lies in the gap between current results and ultimate goals of the university. Therefore, tools to link strategic plans to operational activities are needed for average employees. This article describes conditions and problems of implementing a balanced scorecard at different levels as a modern management tool both in foreign and Russian universities. The given study has practical value and can help to increase the efficiency of university activities.
\end{abstract}

JEL Classification Numbers: P41, I21, I28; DOI: http://dx.doi.org/10.12955/cbup.v5.892

Keywords: BSC, tool, university, education, management, strategy.

\section{Introduction}

A balanced scorecard is an important tool for developing and implementing organizational strategies. It is a relatively new instrument for Russian universities and needs further development because of the need to shift to market principles of functioning with tightened performance requirements on the part of regulatory authorities and the business community. Thus, the improvement of this instrument and its adjustment to the educational environment are of academic and practical significance.

\section{Theoretical Basis of the Study}

In the most general sense, the balanced scorecard (BSC) is a concept for managing strategic development of an enterprise in regard to its performance. As Lawrie and Cobbold demonstrated (2002) the concept has undergone three successive stages of development.

Norton and Kaplan (1997) stressed a basic list of BSC mandatory characteristics on which modern researchers still base. BSC is always a combination of financial and non-financial scores. The number of scores being limited and varying within 15-20-25. The scores are grouped into four blocks called 'Perspectives': 'Finance,' 'Customers,' 'Internal Processes,' and 'Innovation and Training.' The latter two have been subsequently renamed as 'Internal Business Processes' and 'Training and Development.' The scores are selected according to an organization's strategic objective. Typically, one or more types of scores are associated with one target. In selecting the scores, the expert evaluation given by the company's top managers is taken into account. For the company management, forming BSC provides not only the opportunity to use information available to them only, but also ensures their approval and support through personal involvement. There are special causal relations among the four 'Perspectives' that were not clearly described in the early works of Kaplan and Norton (1997), though their existence is noted, as well as the interdependence between measures to improve productivity (lead) and indicators of the measures efficiency (lag).

The initial absence of a clear definition of BSC resulted in numerous attempts to change the original model. These changes mainly considered increasing or decreasing the number of scores and renaming of 'Perspectives' or blocks. In general, this revealed flaws in the earlier development of BSC and encouraged Norton and Kaplan (1997) to develop a second generation BSC. This next version differed to the original in regards to two features:

- Each score type related to a definite strategic objective. That is, the new design aimed to match the strategic objectives with one or more score types and group these into one of the four 'Perspectives'; and

- Causal relations among the strategic objectives were visualized in a 'strategic map.'

A distinct feature of this second BSC version was that it specified and visualized how the perspectives of 'Training and Development,' 'Internal Business Processes,' and 'Customers' connected to the final unit of 'Finance.' It was this change that gave rise to a new wave of disputes and BSC versions. The

\footnotetext{
${ }^{1}$ Faculty of Business, Novosibirsk State Technical University, Russia, mariaarzamastseva94@ gmail.com

${ }^{2}$ Faculty of Business, Novosibirsk State Technical University, Russia, khayrullina@corp.nstu.ru
} 
second-generation model did not suit many organizations. The four blocks (or Perspectives) either excluded important organizational blocks or contained ones that were irrelevant.

There were certain other drawbacks of the second model. Firstly, the second BSC model assumed that the company's mission and strategic plan, on which the balanced scorecard was built, was clear to all members of the management team. Most often, this assumption failed to correspond to what ensued in practice. Secondly, the model did not consider the range of individuals responsible for choosing the above mentioned strategic objectives. Finally, the initial strategic objectives were selected prior to defining their interconnections. That is, the objectives were selected and then their links were depicted in the diagram.

The first-generation model was aimed at the selection of the scores, while the second-generation model focused on the links between the scores and the manner in which they are grouped.

Today the third BSC generation consists of two modules. The first is the Target Report (the Report), which is the reference point for defining strategic objectives. The Report includes several categories to allow those responsible to concentrate and chose specific objectives efficiently easily. For each category, experts forecast and assess the probability of achieving certain objectives by a specific date (typically three years ahead). The second module represents the first-generation mode (Kaplan, 2010). The BSC may seem rather multidimensional and difficult to perceive and build. However, considering the correctly compiled elements of the system and a well-balanced set of scores in unison can achieve a single strategy in any organization. The BSC is a flexible system in terms of opportunity to change its components, and any organization can tailor it for specific goals and objectives.

Relevance of BSC for Universities

For Russian universities, the introduction of BSC is governed by the following critical conditions of the current development stage:

- The opportunity to coordinate strategic objectives with operational activity aimed at implementing the strategy for international competitiveness;

- The relevance of non-financial scores, intangible assets and up-to-date information to ensure the university's business reputation and image;

- Increase in the importance of stakeholder concept due to the significant role of higher education in developing an individual and the society as a whole; and

- A timely response to inconsistencies in business to achieve expected results.

The stages for introducing the BSC into the university management system can be identified as follows:

1. The choice (formulation) of the development strategy;

2. Design of the strategic map;

3. Identification of causal relations;

4. Selection of strategic scores;

5. Development of the motivation and staff encouragement system;

6. Assessment of the extent to which the objectives have been achieved; and

7. Monitoring and adjustment of the strategic plan.

For the leading Russian universities, the strategic objective is to ensure international competitiveness and a listing in world rankings to prove high-level educational quality and graduate demand. Therefore, for universities, the 'Perspectives' need to be linked to the main areas of activity that determine the international competition ranking.

The aim of this study is to 'superimpose' the first generation BSC model on the scorecard defining the position of the best known international rankings. The objective is to build a balanced scorecard for a university to ensure its place in global rankings and provide a solution for current activities.

\section{Data and Methodology}

The first stage involved an analysis of scores of four international rankings: the Quacquarelli Symonds (QS) World University Rankings, the Times Higher Educational World University Rankings (THE), the Academic Ranking of the World Universities (ARWU), and the Ranking Web of universities (Webometrics), as well as two Russian ratings: the National Ranking of Universities and the Ranking of Higher Education Institutes in Russia. 
This analysis identified areas that could be developed to promote international competitiveness and global ratings. These included:

- Education;

- Research work and innovative activities;

- International activities; and

- Entrepreneurial environment.

In the second stage, a sample of leading Russian universities and Novosibirsk State Technical University were assessed for areas that directly or indirectly promoted international competitiveness and global ratings. The former involved 10 Federal and 29 National Research Institutes of Russia included in the Project for enhancing international competitiveness, known as '5/100'. The Novosibirsk State Technical University held the status of a regional support university.

In the third stage, the content of 'Perspectives' for a higher educational institution was analyzed using the traditional BSC model and the strategic objectives defined. Each 'Perspective' had at least one strategic objective in the context of areas defined at Stage 1.

In the fourth stage, the score system obtained in Stage 2 was superimposed on the 'Perspectives' (Stage 3) and areas (Stage 1).

\section{Results and Discussion}

A total of 30 scores was obtained (Table 1). A BSC was developed that met the strategic objectives of international competitiveness and ensured integrated development of current activity aimed at promoting local competitiveness, with the university regional specificity considered (Table 1).

Table 1: The balanced scorecard that met the strategic objectives of international competitiveness and ensured the integrated development of the current university activity

\begin{tabular}{|c|c|c|}
\hline Perspectives & $\begin{array}{l}\text { Strategic objective in the following } \\
\text { directions }\end{array}$ & Scorecard \\
\hline \multirow{4}{*}{ Finance } & $\begin{array}{l}\text { E: Increase in the level of extra- } \\
\text { budgetary funds received from } \\
\text { educational services }\end{array}$ & $\begin{array}{l}\text { 1. Share of income received from extra- } \\
\text { budgetary sources in the total income from } \\
\text { educational activities }(\%)\end{array}$ \\
\hline & $\begin{array}{l}\text { R: Growth in research and development } \\
\text { funding }\end{array}$ & $\begin{array}{l}\text { 2. Volume of research work per staff } \\
\text { member }\end{array}$ \\
\hline & $\begin{array}{l}\text { I: Increase in the number and amount of } \\
\text { international grants }\end{array}$ & $\begin{array}{l}3 \text {. Volume of extra-budgetary funds } \\
\text { received from international grants }\end{array}$ \\
\hline & $\begin{array}{l}\text { B: Growth of funds received from } \\
\text { engineering services, commercialization } \\
\text { of the developed technologies }\end{array}$ & $\begin{array}{l}\text { 4. Share of revenues from commercialized } \\
\text { technologies in the total income from all } \\
\text { sources }(\%)\end{array}$ \\
\hline \multirow[t]{2}{*}{ Customers } & $\begin{array}{l}\text { E: The demand in the university } \\
\text { graduates; } 100 \% \text { employment of } \\
\text { graduates }\end{array}$ & $\begin{array}{l}\text { 5. Average Uniform State Exam score for } \\
\text { university admission } \\
\text { 6. Number of textbooks and teaching aids } \\
\text { developed } \\
\text { 7. Level of employer satisfaction with the } \\
\text { graduate training quality (received via } \\
\text { questionnaire; \%) } \\
\text { 8. Employment rate }(\%)\end{array}$ \\
\hline & $\begin{array}{l}\text { R: Increase in research and } \\
\text { development activities which are } \\
\text { carried out for business and the region }\end{array}$ & $\begin{array}{l}\text { 9. Percentage of Masters/Postgraduate } \\
\text { students in total student population } \\
\text { 10. Percentage of students engaged in } \\
\text { research and development activities on a } \\
\text { paid basis } \\
\text { 11. Number of monographs published }\end{array}$ \\
\hline
\end{tabular}




\begin{tabular}{|c|c|c|}
\hline & $\begin{array}{l}\text { I: Development of academic mobility } \\
\text { through programs of two diplomas, } \\
\text { internships, etc. }\end{array}$ & $\begin{array}{l}\text { 12. Share of foreign students }(\%) \\
\text { 13. Share of foreign teachers }(\%) \\
\text { 14. Number of joint educational programs } \\
\text { (two diploma programs) }\end{array}$ \\
\hline & $\begin{array}{l}\text { B: Development of innovative } \\
\text { entrepreneurship (startups) }\end{array}$ & $\begin{array}{l}\text { 15. Number of successful student startups } \\
\text { 16. The product volume of small innovative } \\
\text { enterprises established at the University }\end{array}$ \\
\hline \multirow{3}{*}{$\begin{array}{l}\text { Internal business } \\
\text { processes }\end{array}$} & $\begin{array}{l}\text { E: Development of e-resources in } \\
\text { management and education (e- } \\
\text { workflow; distance learning } \\
\text { technologies) }\end{array}$ & $\begin{array}{l}\text { 17. The extent to which electronic resources } \\
\text { are applied in research/training/production } \\
(\%)\end{array}$ \\
\hline & $\begin{array}{l}\text { R: Creation of an effective 'innovation } \\
\text { lift' to promote the results from } \\
\text { research and development to the market }\end{array}$ & $\begin{array}{l}\text { 18. Number of income-generating research } \\
\text { and innovative departments }\end{array}$ \\
\hline & $\begin{array}{l}\text { B: Performance maximization of all } \\
\text { departments and employees in terms of } \\
\text { result achievement }\end{array}$ & $\begin{array}{l}\text { 19. Share of the staff performing an } \\
\text { effective contract } \\
\text { 20. The share of departments (managers) } \\
\text { performing an effective contract (\%) }\end{array}$ \\
\hline \multirow{4}{*}{ Capacity } & $\begin{array}{l}\text { E: Development of university human } \\
\text { resource management system } \\
\text { (recruiting; evaluation; training; } \\
\text { promotion) }\end{array}$ & $\begin{array}{l}\text { 21. Percentage of the staff with academic } \\
\text { degrees } \\
22 . \text { Ratio of the teaching staff to the number } \\
\text { of students }\end{array}$ \\
\hline & $\begin{array}{l}\text { R: Close integration of science, } \\
\text { business, education }\end{array}$ & $\begin{array}{l}\text { 23. Level of public and expert activity of } \\
\text { the university staff (\%) } \\
\text { 24. Number of basic chairs } \\
\text { 25. Number of trainees in supplementary } \\
\text { vocational training programs from partner } \\
\text { enterprises }\end{array}$ \\
\hline & $\begin{array}{l}\text { I: Entry into international markets to } \\
\text { attract applicants, teachers, and to } \\
\text { promote the University }\end{array}$ & $\begin{array}{l}\text { 26. Number of publications in international } \\
\text { citation databases (Web of Science, Scopus) } \\
\text { 27. Citation per one staff member in } \\
\text { international citation databases (Web of } \\
\text { Science, Scopus) } \\
\text { 28. Number of unique external links to the } \\
\text { university site pages }\end{array}$ \\
\hline & B: Building of a business environment & $\begin{array}{l}29 . \text { The ratio of the average monthly salary } \\
\text { of a staff member to the average monthly } \\
\text { salary in the region }(\%) \\
30 \text {. The share of funds from all sources } \\
\text { aimed at the development of the property } \\
\text { complex }(\%)\end{array}$ \\
\hline \multicolumn{3}{|l|}{$\begin{array}{l}\text { E: Educational } \\
\text { R: Research } \\
\text { I: International } \\
\text { B: Business }\end{array}$} \\
\hline Source: Author & & \\
\hline
\end{tabular}

It is noted that the perspective of 'finance' denoted the key focus of fundamental change in the Russian universities funding structure, i.e., an overriding proportion of extra-budgetary sources from educational, research, international, and innovative business.

The term 'customers' was applied to students and their parents (as the main customers of educational services) and to business as a consumer of human resources, educational services (additional 
education), and research results. 'Internal business processes' reflected the efficiency of the university management as a whole. This was the weakest point for Russian universities, especially public universities with conservative views of change. 'Capacity' was primarily associated with staff and the environment in which they perform their professional tasks.

Problems of the BSC introduction in Russian universities

The process of Russian universities adapting to new management technologies is affected by attitudes, customs, approaches to the strategic management of public organizations, and other factors. These concerns are fully realized with the introduction of BSC.

The first and main problem is the non-applicability of the classic score set, especially with the perspective of 'finance' in the university environment. The main objective of the public university is to provide educational services and social development and subsequently, the BSC emphasizes scores related to academic activity in contrast to that emphasized for commercial organizations. Thus, the selection of key performance scores for universities is a new and individual process.

The second problem follows on from the first. The methodologies of evaluating any university activity, including national and international rankings, involves a high proportion of qualitative scores, which are less evident and tangible, and thus, difficult to quantify measure and analyze. These include the relevance of research areas carried out by the Chairs, the quality of the subject training, and student satisfaction. There is a problem of objective analysis and evaluation of a significant part of the university performance.

Other classic problems connected with introducing BSC into the management system typical of almost all Russian organizations include the lack of linking strategic objectives with operational activities and inadequate support from upper management.

\section{Conclusion}

The article presents concepts of the mechanisms for integrating the classic BSC model with strategic activities of Russian universities that deal with the challenge of being listed in international rankings. As a result, a balanced scorecard was developed to achieve strategic objectives and integrated growth of current activities.

The study also shows that there are certain problems with introducing BSC in Russian management system. Nevertheless, this tool can form the methodological basis for the management, building, and streamlining of all university processes, indicating a need for further methodological development and follow-up studies.

\section{References}

Abdulsattar Mohammad al-Ali (2012). Developing the Balanced Scorecard Framework for Higher Education: Conceptual study, Proceedings of the 2012 International Conference on Industrial Engineering and Operations Management, Istanbul, Turkey.

Dragunova E. (2006). National features of Russian entrepreneurs: The International Journal of Entrepreneurship and Small Business 3 (5), 607-620.

Dragunova, E. V. (2016). Multidimensional analysis of high-tech companies ' growth potential: 13th International Conference on actual problem of electronics instrument engineering, APEIE-2016: Novosibirsk, Russia: Oct 03-06, 2016. vol. 3. 232-237.

Indrianty, S. (2012). Implementing Balanced Scorecard in the higher education management. Case study: Hasanuddin University of Indonesia, the International Journal of Business and Social Science. Vol. 3 No. 18.

Kaplan R. S. (2010). Conceptual foundation of the balance scorecard. Harvard Business School, Harvard University. Kaplan R. S., Norton D. P. (1996). The Balance scorecard: Translating strategy into action. Harvard Business Review Press, 322

Lawrie, G., Cobbold, I. (2002, May). Development of the 3rd Generation Balanced Scorecard: Evolution of the balanced scorecard into an effective strategic performance management tool. Retrieved from https://2gc.eu/assets/files/resources/Paper s/2GC-WP-201403-Evolution_of_the_BSC.pdf.

Worawit, B., Hajdar, M., Mohd Adam Suhaimi (2014). Employing tools that the balance scorecard (.BSC) to measure performance at higher education-Malaysia, International Journal of Information and communication technology research. 